\title{
ANAK TAK SAH TARAF DARI PERSPEKTIF SYARIAH DAN PERUNDANGAN ISLAM DI MALAYSIA
}

\section{Illegitimate Child from The Perspective of Sharia and Islamic Law in Malaysia}

\author{
Paizah Hj Ismail *
}

\begin{abstract}
Illegitimate child generally means a child born to parents who are not legally married. However, scholars have different opinions on a number of associated conditions. This article aims to analyse the different opinions among scholars and the stand of fatwa in the issue of illegitimate child. This article also analyses Islamic Family Law in Malaysia and its implications for illegitimate child's position in the family particularly in determining the name and inheritance problem. The library research focuses on reanalysing the opinions of classical jurists by taking into account the contemporary context of illegitimate child issues. One of the conclusions of this article is that, to be regarded as a legitimate child by the current Muslim community in Malaysia, the child has to be born as a result of a valid marriage in the eyes of the religion and the Islamic family law of the state.
\end{abstract}

Keywords: Child, Illegitimate Child, Marriage, Islamic Jurisprudence, Islamic Law

* Konsultan, Jabatan Fiqh dan Usul, Akademi Pengajian Islam, Universiti Malaya, Kuala Lumpur, paizahismail@um.edu.my 


\section{PENDAHULUAN}

Sebelum ini, mereka disebut sebagai "Anak Zina". Kemudian sebutan itu dilunakkan sedikit menjadi "Anak Luar Nikah". Kemudian terus dilunakkan lagi sampai disebut sebagai "Anak Tak Sah Taraf". Apa pun juga mereka adalah golongan yang sama. Cuma dilihat dari perspektif atau persekitaran yang berbeza sahaja.

Secara biologinya, $\mathrm{C}$ adalah anak kepada $\mathrm{A}$ yang menyebabkan dia lahir ke dunia melalui ibunya B. Tetapi hakikat biologi ini tidak diiktiraf oleh masyarakat umum. Bagi seorang doktor, bila ditanya $\mathrm{C}$ anak siapa? dia akan menjawab, pastinya ia anak A. Sebaliknya, bagi masyarakat umum, ia bukan anak A tetapi anak tanpa bapa. Kerana ia lahir di luar tradisi masyarakat, iaitu pernikahan. Bagi mereka, antara anak dan bapa perlu ada suatu jenis hubungan sosial yang khusus namanya dalam perkahwinan antara seorang lelaki yang menyebabkan anak itu lahir dan seorang wanita yang melahirkan anak itu. Maksudnya, antara anak dan ayah perlu ada hubungan budaya, iaitu perkahwinan antara ibu dan ayah. Soal biologi tidak berbangkit. Kerana itulah dalam konsep mereka, anak berkenaan bukanlah anak kepada bapa biologi itu tetapi sebaliknya anak tanpa bapa.

Dalam masyarakat beragama, seperti di Malaysia sekarang budaya biasanya berasaskan kepercayaan agama. Maksudnya segala yang berkait dengan hal berkenaan perlu berasaskan kepada ketentuan agama. Bagi agama, khususnya agama Islam hubungan antara lelaki dan wanita berkenaan perlu dimeterai dengan ikatan keagamaan. Tanpa ikatan seperti itu anak yang dilahirkan dianggap anak zina yang tidak mempunyai apa-apa kaitan yang boleh dihormati dengan bapa biologinya.

Undang-undang merupakan satulagi pihak yang berkepentingan dalam masalah berkenaan. Oleh kerana biasanya undang-undang itu merupakan pernyataan daripada kehendak masyarakat, ia akan membuat ketentuan berdasarkan kehendak masyarakat umum, atau biasa juga disebut sebagai kehendak umum masyarakat berkenaan. Oleh kerana masyarakat umum menghendaki mana-mana kelahiran yang sah perlu berdasarkan ikatan perkahwinan yang sah antara lelaki dan perempuan yang terlibat dalam melahirkan 
anak berkenaan, maka undang-undang juga menentukan begitu. Sehubungan dengan persoalan anak yang lahir sebagai hasil daripada perhubungan antara lelaki dan perempuan tanpa ikatan perkahwinan ini undang-undang telah menentukan, ia dari segi undang-undang tidak diiktiraf sebagai anak yang sah.

Selain itu undang-undang juga telah meletakkan prosedur tertentu yang kadang-kala boleh menafikan kehendak budaya dan agama. Dengan mengambil kira kedudukan ini, perkahwinan yang dimaksudkan oleh budaya dan agama itu perlu selaras dengan kehendak yang diperuntukkan dalam undang-undang. Satu perkahwinan yang tidak didaftarkan di bawah undang-undang berkenaan dianggap tidak sah dari segi undang-undang, meskipun sebaliknya dari segi agama dan budaya. Implikasinya, anak yang lahir dari perkahwinan seperti itu walaupun sah dari segi agama dan budaya, iaitu bukan anak zina atau anak luar nikah, namun ia tetap merupakan anak tak sah taraf dari segi undang-undang.

Semua persoalan ini berkait dengan hubungan antara anak berkenaan dengan bapa biologinya. Adapun antara dia dengan perempuan yang melahirkannya persoalan seperti ini tidak timbul. Asalkan sahaja secara biologinya anak itu adalah anaknya, masyarakat dan agama akan megiktiraf hubungan itu. Perempuan itu tetap ibu kepada anak berkenaan walaupun dia telah melahirkan anak itu tanpa melalui perkahwinan yang sah dari segi budaya, agama mahupun dari segi undang-undang.

\section{KONSEP TAK SAH TARAF}

Mengikut Syariat Islam, konsep sah taraf merujuk kepada perakuan yang diperolehi oleh anak berkenaan sebagai anak yang sah kepada bapa berkenaan. Mengikut para fuqaha, perolehan berkenaan boleh berlaku melalui tiga cara. Pertamanya melalui perkahwinan yang sah atau perkahwinan yang fasid antara kedua ibu dan bapa kepada anak berkenaan. Keduanya berlaku persetubuhan secara shubhah antara lelaki dan perempuan berkenaan. Sementara ketiganya pula 
melalui perakuan yang dibuat oleh bapa berkenaan bahawa anak berkenaan adalah anaknya. ${ }^{1}$

Asas utama kepada pandangan ini ialah sabda Rasulullah SAW " 2 " الولد للفراش "yang bermaksud anak perlu dikaitkan (Ilhāq $q$ ) dengan bapa yang melahirkannya melalui perkahwinan yang sah. ${ }^{3}$

Namun bukan semua perkahwinan boleh menjadi asas kepada sah taraf yang dimaksudkan. Mengikut para fuqaha lagi, ia perlu mencapai tempoh enam bulan sebelum anak itu dilahirkan. ${ }^{4}$ Asas kepada pandangan ini adalah kompromi (al-jam $)$ antara pengertian dua ayat al-Quran yang berkait dengan masalah berkenaan. Ayat pertama ialah firman Allah SWT dalam surah al-Ahqaf, ayat 15:

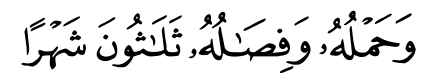

Sementara ayat kedua pula ialah firman Allah SWT dalam surah Luqman, ayat 14:

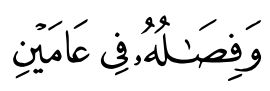

Dalam ayat pertama Allah menyebut tempoh mengandung bersama menyusu adalah selama 30 bulan. Sementara dalam ayat kedua pula Allah menegaskan tempoh menyusu selama dua tahun, iaitu 24 bulan. Ini bererti, mengikut kaedah kompromi berkenaan tempoh terbaki, iaitu enam bulan merupakan tempoh minimum bagi mengandung. ${ }^{5}$

Memperkukuhkan lagi tafsiran ini adalah hadis Ibn 'Abbās dalam kes wanita yang melahirkan anak selepas sahaja genap enam bulan mengandung. Kerana syak dengan kejujuran wanita itu suaminya membawa kes berkenaan kepada Sayyidina 'Uthmān

1 Wahbah al-Zuhaylī, al-Fiqh al-Islāmī wa Adillatuh (Damshiq: Dār al-Fikr, 1985), $7: 675$.

2 Hadis riwayat Abū Dāwūd, al-Nasā'̄ dan Ibn Mājah daripada Abū Hurayrah; al-Syawkānī, Nayl al-Awtạar (al-Qāhirah: Dār al-Jayl, 1973 ), $6: 279$.

3 Al-Zuhaylī, al-Figh al-Islāmī, 676.

4 Ibn Rushd, Bidāyah al-Mujtahid (al-Qāhirah: Mațba'ah al-Kuliyyāt al-Azhariyyah, 1966), $2: 352$.

5 Al-Zuhaylīi, al-Fiqh al-Islāmī, 676. 
Ibn 'Affān. Pada mulanya 'Uthmān RA berkecenderungan untuk menghukum supaya wanita itu direjam. Bagaimanapun beliau telah ditegur oleh Ibn 'Abbās berasaskan kepada kompromi antara dua ayat berkenaan. 'Uthmān menerima baik tafsiran berkenaan lalu melepaskan wanita itu daripada hukuman. ${ }^{6}$

Bagaimanapun, mengikut pandangan majoriti para fuqaha, ${ }^{7}$ yang dimaksudkan dengan enam bulan itu bukan merujuk kepada tempoh akad nikah sahaja, tetapi juga kepada awal tempoh kemungkinan persetubuhan boleh berlaku antara dua suami isteri berkenaan. ${ }^{8}$ Ini kerana perkataan "الفراش" dalam hadis berkenaan bermaksud isteri yang disetubuhi. ${ }^{9}$

Satu syarat lain ialah tempoh maksimum. Maksudnya bayi berkenaan perlu lahir dalam jangka masa perkahwinan yang tidak lebih dari tempoh berkenaan. Walau bagaimanapun, tidak seperti dalam masalah tempoh minimum, pendapat para fuqaha sangat berbeza antara satu sama lain berhubungan dengan persoalan ini.

Dalam mazhab Hanafi, tempoh yang dimaksudkan ialah selama 2 tahun, ${ }^{10}$ iaitu berpandukan pendapat Saydatina Aisyah

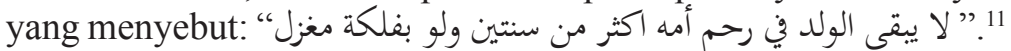
Yang bermaksud "Anak tidak akan berada dalam Rahim ibunya lebih daripada dua tahun walau pun sesaat".

Dalam mazhab Syafii dan Hanbali 4 tahun, iaitu berdasarkan kepada realiti hidup pada waktu itu. Kata mereka, perempuan suku Bani 'Ajlan mengandung selama 4 tahun. ${ }^{12}$ Sementara para fuqaha

6 Al-Kasānī, Badā'i ' al-Șanā'i ‘ (al-Qāhirah: Maktabah al-Jamāliyyah, 1328H), $3: 211$.

7 Al-Zuhaylīi, al-Fiqh al-Islāmī, 676.

8 Bagaimanapun, bagi mazhab Hanafi tafsiran ini tidak terpakai. Baginya yang perlu dihitung dalam perkiraan enam bulan berkenaan ialah bermula dari tarikh akad itu sendiri. Tanpa mengambil kira tempoh kemungkinan berlaku persetubuhan atau sebaliknya. Lihat: Al-Kasān̄̄, Badā'i 'al-Șanā'i ', 212.

9 Al-Zuhaylī, al-Fiqh al-Islāmī, 675-676.

10 Ibn al-Humam, Fath al-Qadīr (al-Qāhirah: al-Halabī, t.t), 3 : 310.

11 Seperti mana yang diriwayatkan oleh al-Dāruquțn̄ dan al-Bayhaqī; al-Syawkānī, Nayl al-Awțār, 281.

12 Al-Sharbīnī al-Khațīb, Mughnī al-Muhtāj (al-Qāhirah: al-Halabī, 1957), $3: 390$. 
mazhab Maliki pula berpendapat 5 tahun. Kata Imam Mālik, saya dengar ada perempuan mengandung selama 7 tahun. ${ }^{13}$

Di pihak yang lain pula ada mazhab berpendapat tempoh maksimum berkenaan ialah setahun (Qamariyah) sahaja. Ini adalah pandangan Muhammad Ibn 'Abd al-Hakam dari mazhab Maliki. ${ }^{14}$ Malah ada yang berpendapat hanya 9 bulan (Qamariyah) sahaja, seperti mana yang dipegang oleh mazhab al-Z̄āhirī. ${ }^{15}$

Ibn Rushd mengulas pendapat berkenaan berdasarkan cakap dengar dari sesetengah kalangan kaum wanita yang berpendapat "perut buncit tanda mengandung". ${ }^{16}$ Antara para ulama semasa yang bersetuju dengan ulasan Ibn Rushd ini ialah al-Shaykh Muhammad Abū Zahrah. Mengikut beliau, hukum seperti ini tidak dijelaskan oleh nas. Sebaliknya ditentukan secara andaian semata-mata. ${ }^{17}$ Tambah beliau lagi, kajian kuantitatif yang dilakukan di zaman kita ini menunjukkan tidak ada kes yang boleh mendokong teori yang mengatakan lima tahun, atau empat tahun, atau dua tahun. Kebanyakan kes yang didapati adalah selama sembilan bulan. ${ }^{18}$ Beliau seterusnya menambah, tempoh paling panjang yang boleh ditolak ansurkan, ialah selama setahun, iaitu berdasarkan prinsip ihțiyāt (bercermat). Dengan itu, kata beliau lagi, pendapat Ibn alHakam dan ahl al-Ẓāhir lebih wajar diterima. ${ }^{19}$

\section{PANDANGAN JAWATANKUASA FATWA KEBANGSAAN}

Muzakarah Jawatankuasa Fatwa Kebangsaan Bagi Hal Ehwal Agama Islam berhubung dengan kedudukan anak tak sah taraf ini yang diadakan pada 1981 membuat keputusan seperti berikut:

"Muzakarah Jawatankuasa Fatwa Kebangsaan Bagi

Hal Ehwal Agama Islam kali ke 1 yang bersidang

\footnotetext{
13 Ibn Rushd, Bidāyah al-Mujtahid, 352.

14 Ibid., 352.

15 Ibn Hazm al-Ẓahirī, al-Muhallā (al-Qāhirah: Maṭba'ah alMuniriyyah, 1972), $10: 385$.

16 Ibn Rushd, Bidāyah al-Mujtahid, 352.

17 Muhammad Abū Zahrah, al-Aḥwāl al-Shakhṣiyyah (al-Qāhirah: Dār al-Fikr al-Arabī, 1957), 453.

18 Muhammad Abū Zahrah, al-Ahwwāl al-Shakhṣiyyah.

19 Ibid.
} 
pada 28-29 Januari 1981 telah membincangkan penamaan Anak Tak Sah Taraf (Anak Luar Nikah). Muzakarah telah memutuskan bahawa anak zina atau anak luar nikah (anak tak sah taraf) samada diikuti dengan perkahwinan kedua pasangan ibu bapanya atau tidak hendaklah dibin atau dibintikan kepada Abdullah." 20

Berdasarkan kepada muzakarah tersebut, 8 negeri iaitu Wilayah Persekutuan Kuala Lumpur, Johor, Melaka, Sarawak, Negeri Sembilan, Terengganu, Selangor dan Pulau Pinang telah mengadaptasikan dan telah memperjelaskan lagi intipati keputusan itu dalam fatwa di negeri-negeri tersebut walau pun dengan menggunakan pelbagai Șighah (wording) yang berbeza. Malah lima daripada negeri-negeri tersebut, iaitu Wilayah Persekutuan Kuala Lumpur, Melaka, Negeri Sembilan, Terengganu dan Selangor telah mewartakan fatwa berkenaan.

Jawatankuasa Fatwa Kebangsaan yang bermuzakarah pada 10 Jun 2003 bersetuju mendefinisikan anak tak sah taraf seperti berikut:

1. Anak yang dilahirkan di luar nikah sama ada akibat zina atau rogol dan dia bukan daripada persetubuhan syubhah.

2. Anak dilahirkan kurang dari 6 bulan 2 laḥzah (saat) mengikut taqwim qamariah daripada tarikh akad nikah.

Walau bagaimanapun, Jawatankuasa Fatwa berkenaan dalam mesyuaratnya pada 27 Julai 2004 telah mengubah ayat "daripada tarikh akad nikah" dihujung parenggan dua menjadi "daripada tarikh tamkin" (setubuh) dengan tujuan untuk memperjelaskan lagi bahawa tempoh 6 bulan 2 saat (lahzah) yang dimaksudkan dalam fatwa sebelumnya tidak bermula pada waktu akad nikah dilakukan tetapi sebaliknya bermula pada ketika terbuka kemungkinan berlaku persetubuhan antara suami isteri berkenaan. Sebagai contoh, perkahwinan berlaku antara wanita tempatan dan lelaki negara lain melalui wakil atau persidangan video, maka

20 Surat Faisal bin Ahmad Sabri, Penasihat Undang-undang JAKIM, bagi pehak Ketua Pengarah JAKIM kepada penasihat Undangundang Jabatan Pendaftaran Negara Malaysia pada 16 Mac 2012. 
masa 6 bulan 2 lahzah itu tidak akan dikira bermula dari tarikh itu tetapi sebaliknya bermula dari tarikh mula-mula lelaki berkenaan sampai di Malaysia. Kerana pada waktu itu barulah persetubuhan mungkin berlaku. ${ }^{21}$

Pandangan tersebut kemudiannya telah diwartakan oleh beberapa negeri di Malaysia untuk menjadi fatwa rasmi di negeri masing-masing.

\section{PERUNTUKAN DALAM UNDANG-UNDANG KELUARGA ISLAM}

Walaupun terdapat negeri-negeri yang tidak mewartakan keputusan muzakarah berkenaan, namun intipati kepada keputusan itu telah diserapkan ke dalam peruntukan undang-undang keluarga Islam yang terdapat di negeri-negeri seluruh Malaysia. Kerana kesemua Akta/Enakmen undang-undang keluarga Islam negeri-negeri di Malaysia adalah menggunakan undang-undang model seragam yang telah diperkenankan oleh mesyuarat Majlis Raja-Raja Melayu kali ke 188 pada 22 Mac 2001.

Mengenai definisi anak tak sah taraf itu sendiri, Undangundang Keluarga Islam Negeri Kelantan No. 6, 2002, misalnya menyebut "Tak sah taraf berhubung dengan seorang anak, ertinya dilahirkan di luar nikah dan bukan anak dari persetubuhan syubhah". ${ }^{22}$ Ungkapan yang sama juga terdapat dalam Undangundang Keluarga Islam Negeri Selangor No. 2, 2003, ${ }^{23}$ Undangundang Keluarga Islam Wilayah Persekutuan, 1984, ${ }^{24}$ Enakmen Undang-undang Keluarga Islam Melaka No. 12, 2002, Enakmen Pentadbiran Undang-undang Keluarga Islam Perlis No. 7, 2006, Enakmen Undang-undang Keluarga Islam Perak No. 6, 2004, Enakmen Undang-undang Keluarga Islam Pulau Pinang No. 3, 2004, Enakmen Undang-undang Keluarga Islam Johor No. 17, 2003, Enakmen Undang-undang Keluarga Islam Kedah K.P.U.

21 Kertas Laporan Kedudukan Isu Anak Tak Sah Taraf yang dikeluarkan oleh Jabatan Kemajuan Islam Malaysia (JAKIM), (t.t.)

22 Enekmen Undang-Undang Keluarga Islam Kelantan No. 6, 2002, sek. 2(1) di bawah perkataan "tak sah taraf"

23 Sek.2.

24 Sek.2. 
13/2008 dan Islamic Family Law Ordinance Sarawak, chap. 43, 2001 .

Ini bererti bahawa pengertian anak tak sah taraf dalam semua Undang-undang Keluarga Islam di Malaysia selaras antara satu sama lain dan selari dengan pandangan para fuqaha seperti mana yang terkandung dalam kebanyakan kitab-kitab fiqh lama dan baru. $^{25}$

Mengenai kesahtarafan anak berkenaan Undang-undang Keluarga Islam negeri-negeri di Malaysia pula rata-rata memperuntukkan perkara yang berkait dengan persoalan siapakah yang dikaitkan sebagai bapa. Dalam Undang-undang Keluarga Islam Kelantan No. 6, 2002 misalnya diperuntukkan:

"Jika seorang perempuan yang berkahwin dengan seorang lelaki melahirkan seorang anak lebih daripada enam bulan qamariyah dari tarikh perkahwinannya itu atau dalam masa empat tahun qamariyah selepas perkahwinan itu dibubarkan sama ada oleh sebab kematian lelaki itu atau oleh sebab perceraian, dan perempuan itu pula tidak berkahwin semula maka lelaki itu disifatkan sebagai bapa anak itu, tetapi lelaki itu boleh dengan cara li'an atau kutukan, menafikan anak itu sebagai anaknya di hadapan Mahkamah." 26

Peruntukan ini bermaksud bahawa tempoh minimum bagi sesuatu perkahwinan itu, bagi tujuan mengesah taraf anak yang lahir melaluinya ialah enam bulan qamariah, sementara tempoh maksimumnya pula ialah empat tahun qamariah selepas perkahwinan itu dibubarkan. Walau bagaimanapun bagi tempoh maksimum ini, selain syarat perempuan itu tidak berkahwin semula dengan orang lain, lelaki berkenaan juga boleh menafikan pengesahan berkenaan melalui $l i$ ' $\bar{a} n$ iaitu suatu prosedur khusus yang dibenarkan kepada para suami sahaja bagi tujuan penafian nasab terhadap mana-mana anak yang dilahirkan oleh isterinya.

25 Muhammad Yūsuf Mūsā, al-Nasab wa Atharuhu, ed. 2 (al-Qāhirah: Dār al-Ma'rifah, 1967), 7-20; 'Abd al-Karīm Zaydān, al-Mufașṣal fì Aḥkām al-Mar'ah wa al-Bayt al-Islāmī fì al-Sharī'ah al-Islāmiyyah, Bayrūt: Mu'ssasah al-Risālah, t.t.), 9 : 341-344.

26 Sek.111. 
Peruntukan yang sama juga terdapat dalam Undang-undang Keluarga Islam bagi negeri-negeri yang lain, misalnya Undangundang Keluarga Islam Negeri Selangor 2003, Melaka 2002, Perak 2004, Pulau Pinang 2004, Wilayah Persekutuan 1984 dan Sarawak 2001. Walau bagaimanapun, dalam Undang-undang Keluarga Islam Negeri Kedah dan Perlis ada sedikit perbezaan tentang tempoh maksimum. Dalam kedua-dua undang-undang tersebut tempoh maksimum yang diperuntukkan ialah setahun sahaja. ${ }^{27}$

Satu peruntukan lain yang berkait dengan tempoh yang membolehkan pengesahtarafan anak berkenaan ialah mengenai perakuan tamat 'iddah. Mengikut peruntukan tersebut, perakuan tamat 'iddah boleh menjadi sebab bagi menghalang anak berkenaan disahtarafkan sebagai anak lelaki berkenaan walaupun ia dilahirkan dalam masa empat tahun perpisahan berlaku. Dalam Undang-undang Keluarga Islam Negeri Kelantan No. 6, 2002 misalnya diperuntukkan:

"Jika seorang perempuan, yang tidak berkahwin semula, membuat suatu pengakuan bahawa tempoh 'iddahnya telah tamat, sama ada 'iddah itu adalah oleh sebab kematian atau perceraian, dan perempuan itu kemudiannya melahirkan seorang anak maka suami perempuan itu tidak boleh disifatkan sebagai bapa anakitu melainkan jika anak itu telah dilahirkan kurang dartipada empat tahun qamariah dari tarikh perkahwinan itu dibubarkan oleh sebab kematian suaminya itu atau oleh sebab perceraian." 28

Seperti juga peruntukan-peruntukan sebelum ini, peruntukan yang sama terdapat juga dalam Undang-undang Keluarga Islam di negeri-negeri lain di Malaysia.

27 Enakmen Undang-undang Keluarga Islam Kedah 1979, sek.99 dan 100; Enakmen Pentadbiran Undang-undang Keluarga Islam Perlis 1992, sek.109 dan 110.

28 Sek.113. 


\section{IMPLIKASI ANAK TAK SAH TARAF}

Terdapat dua implikasi terhadap anak tak sah taraf ini dalam kehidupan peribadi anak berkenaan. Pertamanya, masalah nama atau tegasnya "Bin" atau "Binti" yang menunjukkan beliau anak siapa, dan keduanya masalah pembahagian harta pusaka.

\section{Implikasi Terhadap Penamaan}

Mengenai nama atau tegasnya "Bin" atau "Binti" tidak banyak perbincangan yang dibuat oleh para fuqaha mengenainya. Seolah-olah persoalan berkenaan hanyalah sekadar suatu perkara berbangkit daripada fatwa mereka tentang sabit atau tidak nasab keturunan antara anak zina dengan bapa biologinya. Oleh kerana perbincangan di atas merumuskan bahawa anak yang dilahirkan dengan cara yang tidak menepati kehendak Syariat Islam tidak boleh disabitkan nasabnya dengan bapa biologinya maka secara berbangkit dia tidak boleh di "Bin" atau "Binti" kan dengan bapa biologi itu.

Pendapat seperti ini merupakan pandangan yang difatwakan oleh Jawatankuasa Fatwa Kebangsaan kali ke-41 yang diadakan pada 25 Jun 1998. Penamaan tersebut menyebut:

1. Jika seorang perempuan Melayu Islam bersekedudukan tanpa nikah, sama ada dengan lelaki Islam atau lelaki bukan Islam dan melahirkan anak, maka anak itu hendaklah dibin atau dibintikan Abdullah atau lain-lain nama “Asmā' al-Husnā" berpangkalkan Abdul.

2. Seorang anak tak sah taraf atau anak luar nikah tidak wajar dibin atau dibintikan kepada ibu anak tersebut kerana ini mungkin boleh menimbulkan masalah sosial dan kesan psikologi kepada kanak-kanak itu. Oleh yang demikian anak tersebut dibin atau dibintikan kepada Abdullah atau lain-lain nama “Asmā' al-Husna $\vec{a}$ ” berpangkalkan Abdul.

3. Seseorang anak yang dijumpai terbiar atau anak pungut yang tidak diketahui asal usulnya hendaklah dibin atau dibintikan Abdullah, dan jika nama Abdullah bersamaan dengan orang yang memelihara anak itu, maka bolehlah 
dipilih nama "Asmā' al-Husnä" lain yang berpangkalkan Abdul seperti Abdul Rahman dan Abdul Rahim.

\section{Implikasi Terhadap Pusaka}

Sama seperti masalah penamaan, masalah pusaka bagi anak tak sah taraf juga tidak dibincang secara lanjut oleh para fuqaha kerana ia merupakan implikasi daripada kedudukan berkenaan yang sangat senang difahami. Maksudnya, oleh kerana anak tak sah taraf itu tidak ada apa-apa kaitan kekeluargaan dengan bapa biologinya, maka soal pusaka antara keduanya tidak berbangkit.

Berbeza sekali dengan masalah pusaka antara anak berkenaan dengan ibu yang melahirkannya kerana apabila sudah jelas bahawa anak berkenaan, dalam keadaan apa sekalipun adalah anaknya yang sah kepadanya. Maka segala perkara yang berkait dengan kedudukan berkenaan akan berlaku seperti biasa, termasuk masalah pusaka. Dengan kata lain, hukum pusaka akan berlaku antara keduanya tanpa mengira siapa yang mempusakai siapa.

Di Malaysia, hukum ini menjadi asas kepada pandangan yang diberikan oleh Jawatankuasa Fatwa Kebangsaan yang bersidang pada 25 Jun 1998, yang memutuskan seperti berikut:

"Anak tak sah taraf tidak terputus hubungan keturunan dengan ibunya. Oleh itu kedua-duanya boleh mewarisi pusaka antara satu sama lain. Jika ibu meninggal dunia, maka dia berhak mewarisi pusaka ibunya bersama-sama ahli waris yang lain. Begitu juga sekiranya anak tak sah taraf itu meninggal dunia terlebih dahulu, ibunya berhak mewarisi pusaka."

"Seseorang anak tak sah taraf adalah terputus hubungan daripada segi pusaka dengan bapanya tak sah taraf dan dia tidak menjadi ahli waris dan tidak berhak mewarisi pusaka bapanya dan sebaliknya." 


\section{PENUTUP}

Sebagai penutup, adalah wajar diperingatkan bahawa Islam mempunyai sistem kekeluargaan yang cukup jelas dan terancang. Dasarnya ialah tidak ada apa-apa hubungan kekeluargaan kecuali berasaskan kepada perkahwinan yang sah. Sebab itulah bila sahaja Islam datang, ia telah mengharamkan sistem anak angkat yang dijadikan sebagai asas kepada pembinaan keluarga dinasabkan kepada bapa angkat. Ini kerana ia merupakan satu sistem yang sangat longgar dan tidak berupaya menjamin ikatan kekeluargaan yang terkawal. Semuanya ini bertujuan untuk menjaga kesucian keluarga daripada unsur-unsur luaran yang tidak sesuai dengan kerukunan rumahtangga berkenaan.

Berasas kepada hakikat inilah juga, Islam tidak mengiktiraf anak zina sebagai anak yang mempunyai ikatan kekeluargaan yang sah dengan bapa biologinya. Kerana bagi Islam, pernikahan adalah satu-satunya asas yang boleh menjadikan hubungan biologi sebagai sah dan diiktiraf. Ia dilihat sebagai satu ikatan suci yang mampu menjadikan kekeluargaan sebagai sebahagian daripada keagamaan itu sendiri.

\section{BIBLIOGRAFI}

Abū Zahrah, Muḥammad. Al-Ahwwāl al-Shakhșiyyah. al-Qāhirah: Dār al-Fikr al-Arab̄ì, 1957.

Al-Kasān̄i. Badā'í al-Ṣanā'í. al-Qāhirah: Maktabah alJamāliyyah, 1328H.

Al-Khațīb, al-Sharbīnī. Mughnī al-Muḥtāj. al-Qāhirah: al-Ḥalabī, 1957.

Al-Z̄āhirī, Ibn Ḥazm. al-Muhallā. al-Qāhirah: Maṭba'ah alMuniriyyah, 1972.

Al-Zuhaylī, Wahbah. al-Fiqh al-Islāmī wa Adillatuh. Damshiq: Dār al-Fikr, 1985.

Ibn al-Ḥummam. Fath al-Qadīr. al-Qāhirah: al-Ḥalabī, t.t. 
Ibn Rushd. Bidāyah al-Mujtahid. al-Qāhirah: Maṭba'ah alKulliyah al-Azhariyyah, 1966.

Jabatan Kemajuan Islam Malaysia (JAKIM), Surat Faisal Bin Ahmad Sabri, Penasihat Undang-Undang JAKIM Bagi Pehak Ketua Pengarah JAKIM Kepada Penasihat Undang-Undang Jabatan Pendaftaran Negara Malaysia, Kuala Lumpur: Jabatan Kemajuan Islam Malaysia, (tidak diterbitkan), 2012.

. "Kedudukan Isu Anak Tak Sah Taraf". Kuala Lumpur: (tidak diterbitkan), t.t.

. "Kertas Laporan Kedudukan Isu Anak Tak Sah Taraf'. Kuala Lumpur: (tidak diterbitkan), t.t.

Kerajaan Negeri Kedah. Enakmen Undang-undang Keluarga Islam Kedah, 1979.

Kerajaan Negeri Kelantan. Enakmen Undang-undang Keluarga Islam Kelantan No. 6, 2002.

Kerajaan Negeri Perlis. Enakmen Pentadbiran Undang-undang Keluarga Islam Perlis, 1992.

Majlis Kebangsaan Bagi Hal Ehwal Agama Islam Malaysia. "Mengahwini Perempuan Yang Sedang Mengandung Anak Luar Nikah", Kuala Lumpur: (tidak diterbitkan), 1971.

. "Penamaan Anak Tak Sah Taraf (Anak Luar Nikah)". Kuala Lumpur: (tidak diterbitkan), 1981.

. "Fatwa mengenai Anak Tak Sah Taraf". Kuala Lumpur: (tidak diterbitkan), 2003.

Mūsā, Muhammad Yūsuf. al-Nasab wa Atharuhu. al-Qāhirah: Dār al-Ma'rifah, 1967.

Muhamad Sujimon. The Problem of The Illegitimate Child in The Sunni Schools. Kuala Lumpur: IIUM Press, IIUM, 2010.

Zaydān, 'Abd al-Karīm. al-Mufașșal fì Ahkām al-Mar'ah wa al-Bayt al-Islāmī fì al-Sharī'ah al-Islāmiyyah. Bayrūt: Mu'assasah al-Risālah, t.t. 